\title{
GNAS1 Mutation Identified in Genomic DNA from Whole Blood of a Case with McCune-Albright Syndrome
}

\author{
Noboru Igarashi ${ }^{1}$, Katsuaki Motomura ${ }^{2}$ and Eiichi Kinoshita ${ }^{2}$ \\ ${ }^{1}$ Department of Pediatrics, Toyama Prefectural Central Hospital, Toyama, \\ ${ }^{2}$ Department of Pediatrics, Nagasaki University School of Medicine, Nagasaki, Japan
}

\begin{abstract}
We present the case of a 1 yr and 9 mo old girl with McCune-Albright syndrome (MAS), who was identified as having a GNAS1 activation mutation in peripheral blood cells. Our clinic was consulted because of the patient's recurrent vaginal bleeding from the early infantile period. We noticed that she had gonadotropin independent precocious puberty due to autonomic functioning ovarian cysts and subclinical hyperthyroidism without autoimmunity. Radiological studies indicated bone lesions as fibrous dysplasia in her right femur and tibia. We diagnosed this case as MAS, and GNAS1 mutation analysis using genomic DNA from whole blood was performed by nested PCR and restriction endonuclease digestion. The patient had a GNAS1 activating mutation of Arg(CGT)201 $\rightarrow$ His(CAT). Previously GNAS1 mutation has been reported in extracted tissues such as bone lesions or affected endocrine organs. Our mutation analysis using blood cells with sensitive PCR and restriction enzyme is a non-invasive method for the genetic diagnosis of MAS, and would also be useful for early definitive diagnosis of non-classic MAS a wide clinical spectrum.
\end{abstract}

Key words: McCune-Albright syndrome, GNAS1, PCR

\section{Introduction}

McCune-Albright syndrome (MAS) is characterized by the triad of precocious puberty, café-au-lait spot, and polyostotic fibrous dysplasia. It is caused by point mutations of GNAS1, the gene encoding the alpha subunit of the stimulatory Gprotein $(\mathrm{Gs} \alpha)$, which leads to constitutive activation of Gs $\alpha$ and stimulation of cyclic-AMP production $(1,2)$. This mutation has been reported in various tissues, including the thyroid gland, ovary, skin lesions, bone lesions, and pituitary

Correspondence: Dr. Noboru Igarashi, Department of Pediatrics, Toyama Central Prefectural Hospital, NishiNagae 2-2-78, Toyama City 930-8550, Japan tumors (2). In this report, we present the case of a girl with MAS, who showed a mutation of the Gsa gene in whole blood cells.

\section{Case Presentation}

The parents of a $1 \mathrm{yr}$ and 9 mo old girl consulted our clinic because of her recurrent vaginal bleeding from 2 mo old. She was the first child of non-consanguineous parents with a birth weight of $2690 \mathrm{~g}$ at the 40th week of gestation. At another clinic, she was diagnosed as having an ovarian cyst, and her sexual development progressed. Her physical findings were as follows: height $84.5 \mathrm{~cm}(+0.6 \mathrm{SD})$, weight $11.0 \mathrm{~kg}$, mammary Tanner stage III, pubic hair Tanner 
Table 1 Serum and urinary laboratory data on first examination

\begin{tabular}{lll}
\hline TSH & $<0.01 \mu \mathrm{IU} / \mathrm{ml}$ & $(0.35-4.94)$ \\
$\mathrm{F}^{-} \mathrm{T}_{4}$ & $1.8 \mathrm{ng} / \mathrm{dl}$ & $(0.70-1.48)$ \\
$\mathrm{F}_{3}$ & $7.2 \mathrm{pg} / \mathrm{ml}$ & $(2.47-4.34)$ \\
Anti TPO Ab & $<0.3 \mathrm{U} / \mathrm{ml}$ & $(<0.3)$ \\
Anti Tg Ab & $<0.3 \mathrm{U} / \mathrm{ml}$ & $(<0.3)$ \\
${ }^{223} \mathrm{~T}$ Thyroid uptake $(3 / 24 \mathrm{hrs})$ & $17.6 / 23.8 \%$ & $(10-35)$ \\
SM-C & $361 \mathrm{ng} / \mathrm{ml}$ & $(37-229)$ \\
$\mathrm{E}_{2}$ & $<10 \mathrm{pg} / \mathrm{ml}$ & $(<10)$ \\
Testosterone & $<0.1 \mathrm{ng} / \mathrm{ml}$ & $(<0.1)$ \\
DHEA-S & $167 \mathrm{ng} / \mathrm{ml}$ & $(28-223)$ \\
Morning urinary GH & $72.7 \mathrm{pg} / \mathrm{mg} . \mathrm{Cr}$ & $(17.0-107.0)$ \\
Urinary free cortisol & $40.2 \mathrm{mg} / \mathrm{m} / \mathrm{day}$ & $(25-75)$ \\
Cortisol & $19.5 \mathrm{mg} / \mathrm{dl}$ & $(5.0-17.9)$ \\
PRL & $22.3 \mathrm{ng} / \mathrm{ml}$ & $(<15.0)$ \\
$\beta$-HCG & $<0.10 \mathrm{ng} / \mathrm{ml}$ & $(<0.1)$ \\
AFP & $3.5 \mathrm{ng} / \mathrm{ml}$ & $(<10.0)$ \\
LH-RH test & & \\
LH & $<0.5 \rightarrow<0.5 \mathrm{mIU} / \mathrm{ml}$ & \\
FSH & $<0.5 \rightarrow<0.5 \mathrm{mIU} / \mathrm{ml}$ & \\
\hline
\end{tabular}

stage II, axillary hair (-), goiter (-). Faint brown pigmentation was noticed in her nuchal skin area, but this lesion was not conclusive as café-au-lait spot. Findings of skeletal deformity were not observed, and the child complained of no symptoms related to bone lesions such as pain or fracture. Bone age was $4 \mathrm{yr}$ and 2 mo old by the Japanese standardized TW2 method. Laboratory data (Table 1) indicated a case with gonadotropinindependent precocious puberty and hyperthyroidism without autoantibody. The patient did not show any signs of hyperthyroidism during her treatment course. Other hyperfunctioning endocrinopathies involving $\mathrm{GH}$, cortisol, PRL, and PTH were not detected. Biochemical markers of bone absorption such as urinary deoxypiridinoline (DYP) and serum carboxyl terminal cross-linked telopeptide of type 1 collagen (1CTP) were increased, but in contrast, the markers of bone formation such as serum carboxyl-terminal propeptide of type 1 procollagen (P1CP) and osteocalcin were within normal ranges
(Table 2), indicating the bone absorptiondominant bone metabolism as reported previously in MAS(3). Figure 2 shows the serial ultrasonography and CT ovarian findings of this case. Autonomic ovarian cysts of $1.6 \sim 2.5 \mathrm{~cm}$ diameter were detected intermittently during follow-up studies for 6 mo (Fig. 1). On bone scintigraphy using Tc-99m HMDP, there were abnormal accumulations in the patient's right femur and tibial bones, and her right femur cortex was thinner compared to that of the left femur (Fig. 2 ). These findings might suggest a case of fibrous dysplasia. Based on the clinical features of precocious puberty due to a functioning ovarian cyst, bone lesions, and subclinical hyperthyroidism without autoimmunity, we diagnosed this case as MAS.

The patient received medroxyprogesterone acetate $\left(\right.$ Provera $\left.^{\mathrm{R}}\right) 5 \mathrm{mg} /$ day and thimasole $\left(\mathrm{MMI}^{\mathrm{R}}\right.$ ) $2.5 \mathrm{mg} /$ day from $1 \mathrm{yr}$ and $10 \mathrm{mo}$ of age, and thereafter her vaginal bleeding stopped and the hyperthyroidism was well controlled (Fig. 3). 
Table 2 Ca and bone metabolism data

\begin{tabular}{lll}
\hline $\mathrm{Ca}$ & $9.7 \mathrm{mg} / \mathrm{dl}$ & \\
$\mathrm{P}$ & $5.1 \mathrm{mg} / \mathrm{dl}$ & \\
Alp & $1294 \mathrm{IU} / \mathrm{l}$ & \\
$\mathrm{U}-\mathrm{Ca}$ & $0.04 / \mathrm{mg} . \mathrm{Cr}$ & \\
$\mathrm{U}-\mathrm{P}$ & $1.58 / \mathrm{mg} . \mathrm{Cr}$ & \\
$\% \mathrm{TRP}$ & $91 \%$ & \\
$\mathrm{PTH}$ & $223 \mathrm{pg} / \mathrm{ml}$ & $(180-560)$ \\
$1,25(\mathrm{OH})_{2} \mathrm{D}_{3}$ & $74.6 \mathrm{pg} / \mathrm{ml}$ & $(20-70)$ \\
$\mathrm{U}-\mathrm{DYP}$ & $91 \mathrm{pmol} / \mu \mathrm{mol} . \mathrm{Cr}$ & $(41 \pm 15)$ \\
$1 \mathrm{CTP}$ & $43.6 \mathrm{ng} / \mathrm{ml}$ & $(16.6 \pm 4.9)$ \\
P1CP & $540 \mathrm{ng} / \mathrm{ml}$ & $(486 \pm 324)$ \\
Osteocalcin & $38 \mathrm{ng} / \mathrm{ml}$ & $(23 \pm 14)$ \\
Lumbar spine mineral density (DEXA) & $0.452 \mathrm{~g} / \mathrm{cm}^{2}$ & $(0.35-0.53)$ \\
\hline
\end{tabular}

U-DYP: urinary deoxypyridinoline. 1CTP: carboxy terminal cross-linked telopeptide of type 1 collagen. PICP: carboxy terminal propeptide of type 1 procollagen.
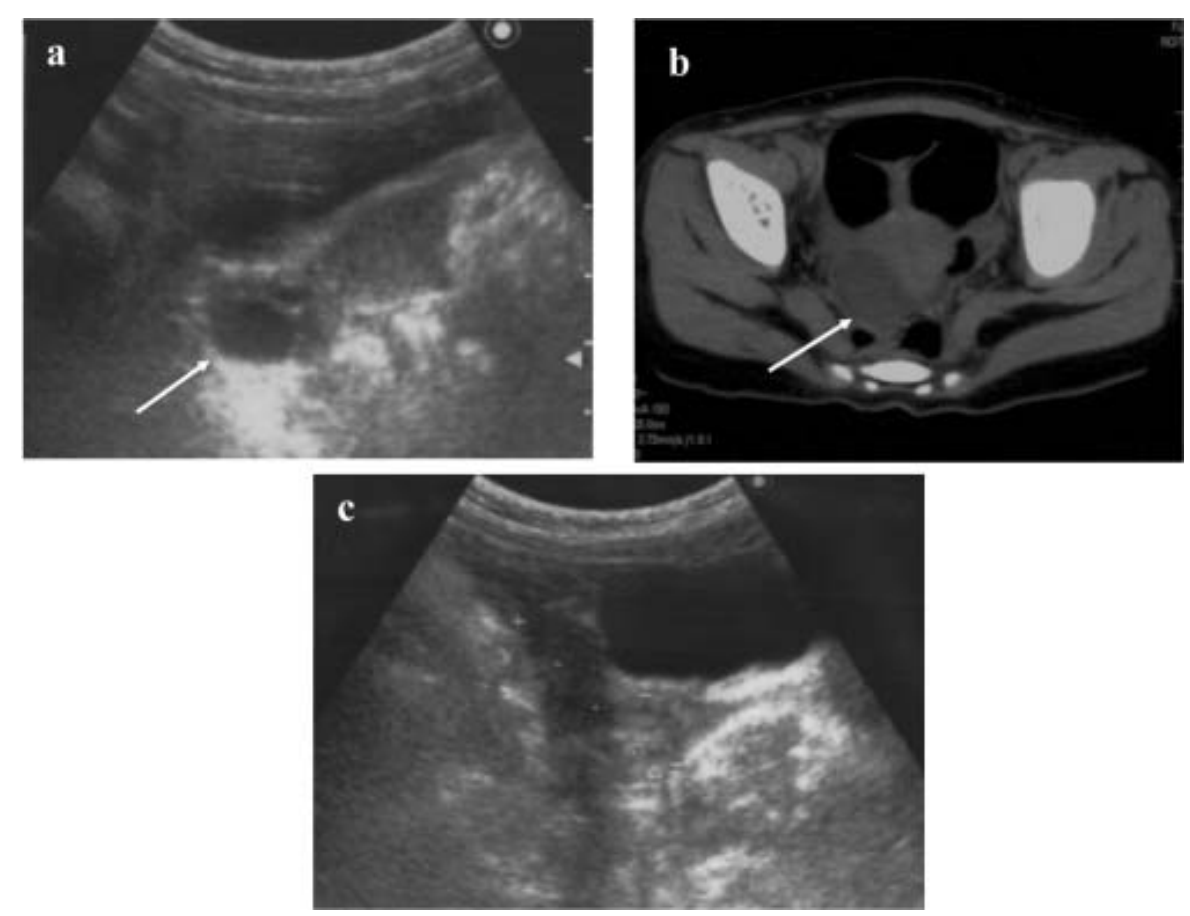

Fig. 1 Serial findings of ultrasonography (a, c) and CT (b) studies of the patient's uterus and ovaries. Upper left panel (a) at $1 \mathrm{yr}$ and 9 mo old with $1.6 \mathrm{~cm}$ left ovarian cyst (arrow). Upper right panel (b) at $1 \mathrm{yr}$ and 11 mo old with $2.5 \mathrm{~cm}$ right ovarian cyst (arrow). Lower panel (c) at 2 yr and 5 mo old without ovarian cysts. 

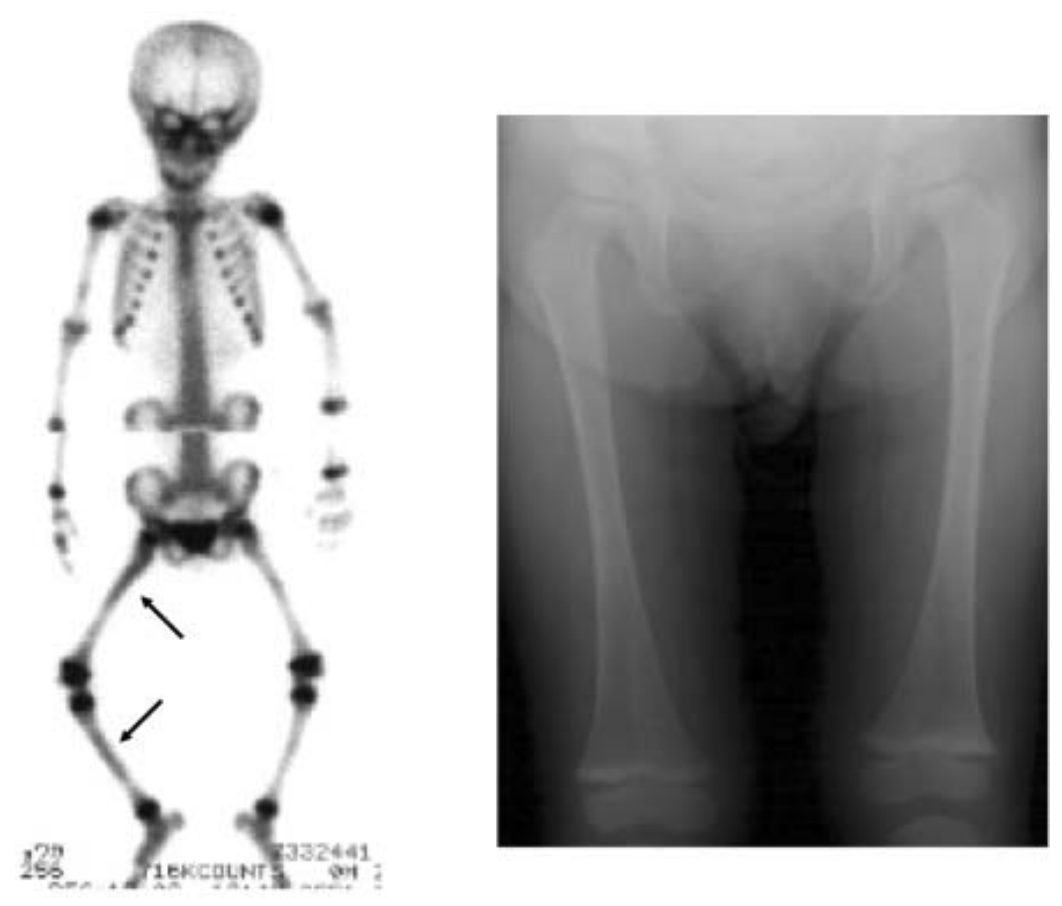

Fig. 2 Bone scan using Tc99m-HMDP (left panel) showed abnormal accumulations in the patient's right femur and tibia (arrows). Radiograph of her femurs indicated a thinner cortex of the right bone (right panel).

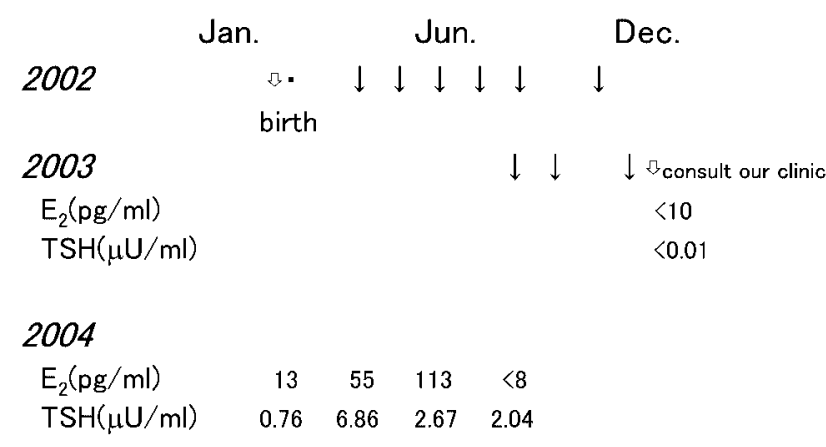

Provera $^{\mathrm{R}}(\mathrm{mg} /$ day $) 5 \rightarrow \rightarrow$

$\operatorname{MMI}(\mathrm{mg} /$ day $) \quad 5 \rightarrow 2.5 \rightarrow \rightarrow$

Fig. 3 Episodes of vaginal bleeding $(\downarrow)$ and the patient's clinical course.

However her estradiol levels markedly fluctuated associated with the autonomic ovarian cyst, and her sexual development progressed further.

\section{Method}

Nested PCR with restriction endonuclease digestion $(4,5)$.

Nested PCR amplification and selective restriction endonuclease digestion of the wild-type allele was performed as described by Hannson with minor modification by Motomura et al. $(4,5)$. PCR amplification introduces a mutation into the products, which introduce a unique EagI restriction site into only the wild-type genomic DNA sequence. Substitution of nucleotides of Arg201 to another amino acid residue abolishes the EagI restriction site, making mutant DNA resistant to degradation by the enzyme. Genomic DNA was extracted from whole blood cells, and two rounds of EagI digestion and amplification of PCR products resistant to degradation were performed. The final PCR products were analyzed by the direct 

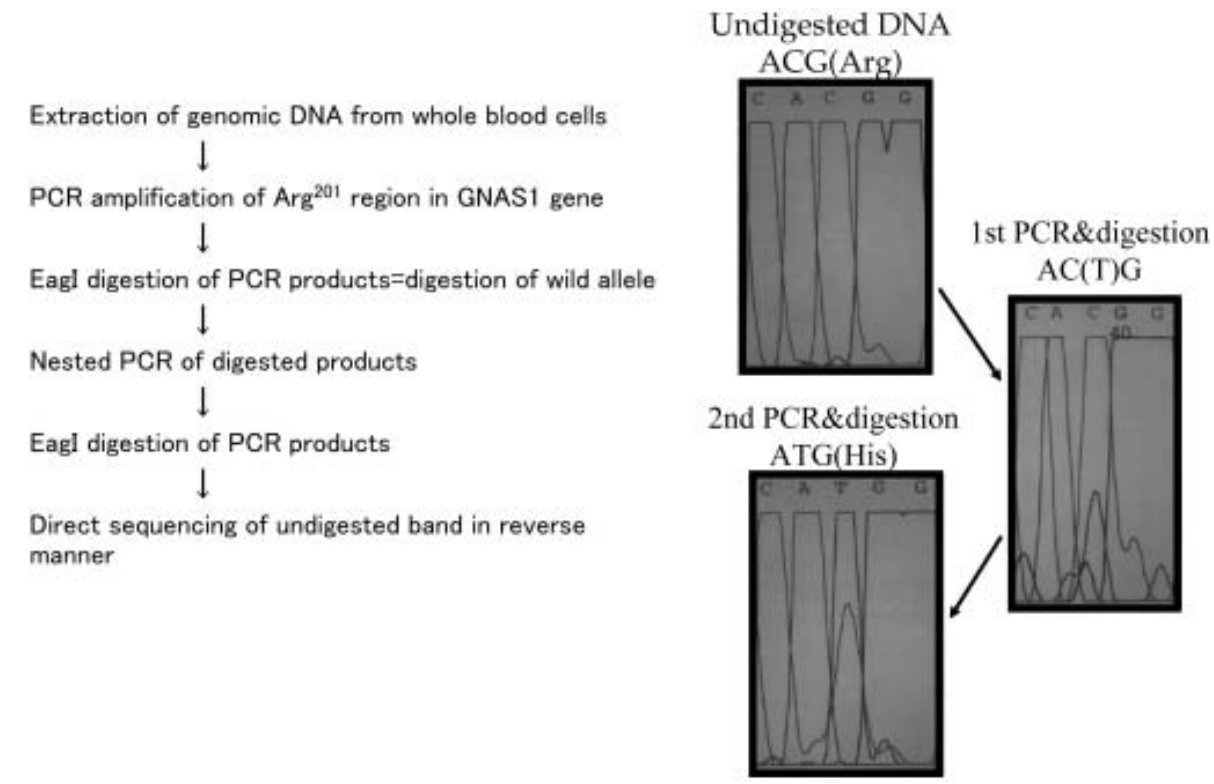

Fig. 4 PCR analysis of GNAS1 mutation using genomic DNA from whole blood cells.

sequencing method in a reverse manner.

\section{Result}

The patient had a GNAS1-activating mutation of $\operatorname{Arg}(\mathrm{CGT}) 201 \rightarrow \mathrm{His}(\mathrm{CAT})$ in genomic DNA from peripheral blood (Fig. 4).

\section{Discussion}

GNAS1 mutations in MAS occur as postzygotic somatic mutations, and the subsequent mosaic distribution is widespread and restricted depending on the timing of the mutation (4). Therefore the mutations can be better found in the tissues Involved in MAS, such as bone lesions, skin lesions, and affected endocrine organs $(1,2)$. Previously, it has been suggested that it is rarely possible to detect GNAS1 mutations in genomic DNA from peripheral blood (4). In this study, we could identify activation mutations in genomic DNA from whole blood cells by using a sensitive
PCR method with restriction endonuclease digestion. Blood is a convenient source of DNA and our mutation analysis is a non-invasive method for genetic diagnosis of MAS. However it remains to be elucidated whether the GNAS1 mutations detected in whole blood actually occurred in blood cells or in cells from tissues Involved in MAS that have been shed into blood as described by Hannon et al. (4).

In our case, the patient's bone lesions or hyperthyroidism were not clinically apparent and were not noticed until closer examination. There was a faint brown pigmentation in the patient's nuchal area, which was not a definitive so-called café-au-lait spot. It is known that there is a wide clinical spectrum in MAS resulting from the distribution of the activating Gso mutation (6). In non-classic MAS, as In our case, isolated ovarian cyst, isolated fibrous dysplasia, or $2 / 3$ classic manifestations with or without additional endocrinopathy, our mutational analysis would be especially useful for early and definitive diagnosis of this rare disease (4). 


\section{References}

1. Weinstein LS, Shenker A, Gejman PV, Merino MJ, Friedman E, Spigel AM. Activating mutations in the stimulatory G protein in the McCune-Albright syndrome. N Engl J Med 1991;325:1688-95.

2. Schwindinger WF, Francomano CA, Levine MA. Identification of a mutation in the gene encoding the subunit of the stimulatory G protein of adenylyl cyclase in McCune-Albright syndrome. Proc Natl Acad Sci 1992;89:5152-6.

3. Yamamoto T, Ozono K, Kasayama S, Yoh K, Hiroshima K, Takagi M, et al. Increased IL-6 production by cells isolated from the fibrous bone dysplasia tissues in patients with McCune-Albright syndrome. J Clin Invest 1996;98:30-5.

4. Hannon TS, Noonan K, Steinmetz R, Eugster EA, Levein MA, Pescovitz OH. Is McCune-Albright syndrome overlooked in subjects with fibrous dysplasia of bone? J Pediatr 2003;142:532-8.

5. Motomura K, Kinoshita E, Yoshimoto M. A simple genetic diagnosis of McCune-Albright syndrome: detection of mutations Arg(201)Cys in GNAS1 gene using peripheral blood. In: Abstract of 40th meeting of Japanese pediatric endocrinology. 2003. p. 0-50 (in Japanese).

6. Eugster EA. McCune-Albright syndrome. In: Current review of pediatric endocrinology. Serono Symposia USA. 2001. p. 109-16. 